Three diets with a lysine concentration of $6.8,7.8$ and $8.8 \mathrm{~g} / \mathrm{kg}$ diet were offered ad libitum to the pigs individually penned from 25 to $95 \mathrm{~kg}$ live weight.

Daily feed intake of entire males and females was similar and lower (by $5.7 \%$ ) than that of castrated males. females.

Daily gain of entire males and castrated males was similar and lower (by 6-10\%) than that of

Feed efficiency measured by the feed conversion ratio was similar in females and castrated males (slightly better in the former). It was $8 \%$ higher in entire males than in the other animals.

Muscle percentage was similar in carcasses of females and entire males and $6 \%$ higher than that of castrated males. Carcasses of entire males exhibited the lowest fat content.

The maximum response to dietary lysine differed according to the sex, the parameter measured and the growth period (25-60 or $60-95 \mathrm{~kg}$ live weight). In entire males and females the better feed efficiency was obtained with $8.8 \mathrm{~g}$ lysine $/ \mathrm{kg}$ diet, whereas in castrated males no further response was achieved above $7.8 \mathrm{~g}$ lysine $/ \mathrm{kg}$ diet.

Higher levels of dietary lysine may be required to detect possible response differences between entire males and females.

\title{
Effect of protein and lysine level in the diet on growth performance and energy utilization in the growing pig
}

\author{
J. NOBLET, Y. HENRY, S. DUBOIS
}

INRA, Station de Recherches Porcines, Saint-Gilles, 35590 L'Hermitage

Three diets containing 15.3 and $0.67 \%$ (diet pl), 15.3 and $0.80 \%$ (diet $\mathrm{pL}$ ) and 17.8 and $0.80 \%$ (diet PL) crude protein and lysine, respectively, were fed to female pigs with an initial live weight of $20 \mathrm{~kg}$. Eight replicates of four littermates were used. In each replicate, one female was slaughtered at the start of the experiment and the three others were given the experimental diets and were slaughtered seven weeks later. Carcasses were dissected, minced and analysed to determine the nature (muscle, adipose tissue...) and chemical composition (protein, lipid...) of the gain and to measure energy and nitrogen balance over the experimental period. Average daily gain and gain in carcass and muscle or protein deposition were lower with the pl diet whereas fat deposition was higher. The decrease in the supply of non essential nitrogen (pL vs PL) did not change average daily gain or gain in carcass or muscle but tended to increase fat deposition. At similar ME intakes, heat production and excretion of nitrogen and energy in urine were higher in PL-fed pigs. Our results suggest that in order to keep constant the amount of retained energy a $1 \%$ increase in the protein level of the diet (at similar limiting amino acid levels) requires 1.0 and $0.75 \%$ additional supply of $\mathrm{DE}$ and $\mathrm{ME}$, respectively.

\section{Reduction in the protein content of diets for weaned piglets : contribution to the study of threonine requirement}

\author{
F. GATEL, J. FEKETE
}

\author{
I.T.C.F., 8, avenue du Président-Wilson, 75116 Paris
}

A trial was made in 384 piglets between 10.6 and $25 \mathrm{~kg}$ live weight housed in pens of 7 animals each and fed an experimental diet for 28 days from the 14 th day after weaning. Four diets 